\title{
Workshop report: Exploring deep oceanic crust off Hawai'i
}

\author{
Susumu Umino ${ }^{1}$, Gregory F. Moore ${ }^{2}$, Brian Boston ${ }^{3}$, Rosalind Coggon ${ }^{4}$, Laura Crispini ${ }^{5}$, \\ Steven D'Hondt ${ }^{6}$, Michael O. Garcia ${ }^{2}$, Takeshi Hanyu ${ }^{7}$, Frieder Klein ${ }^{8}$, Nobukazu Seama ${ }^{9}$, \\ Damon A. H. Teagle ${ }^{4}$, Masako Tominaga ${ }^{10}$, Mikiya Yamashita ${ }^{7,11}$, Michelle Harris ${ }^{12}$, Benoit Ildefonse ${ }^{13}$, \\ Ikuo Katayama $^{14}$, Yuki Kusano ${ }^{15}$, Yohey Suzuki ${ }^{16}$, Elizabeth Trembath-Reichert ${ }^{17}$, Yasuhiro Yamada $^{18}$, \\ Natsue Abe ${ }^{18}$, Nan Xiao $^{18}$, and Fumio Inagaki ${ }^{18}$ \\ ${ }^{1}$ School of Geosciences and Civil Engineering, College of Science and Engineering, \\ Kanazawa University, Kanazawa 920-1192, Japan \\ ${ }^{2}$ Department of Earth Sciences, University of Hawai 'i at Mānoa, Honolulu, HI 96822, USA \\ ${ }^{3}$ Lamont-Doherty Earth Observatory, Columbia University, Palisades, NY 10964, USA \\ ${ }^{4}$ School of Ocean and Earth Science, National Oceanography Centre Southampton, \\ University of Southampton, Southampton SO14 3ZH, UK \\ ${ }^{5}$ Department of Earth, Environment and Life Sciences, University of Genoa, 16126 Genoa, Italy \\ ${ }^{6}$ Graduate School of Oceanography, University of Rhode Island, Narragansett, RI 02882, USA \\ ${ }^{7}$ Research Institute for Marine Geodynamics, Japan Agency for Marine-Earth Science and Technology \\ (JAMSTEC), Yokosuka 237-0061, Japan \\ ${ }^{8}$ Department of Marine Chemistry and Geochemistry, Woods Hole Oceanographic Institution, \\ Woods Hole, MA 02543, USA \\ ${ }^{9}$ Department of Planetology, Graduate School of Science, Kobe Ocean-Bottom Exploration Center (KOBEC), \\ Kobe University, Kobe 657-8501, Japan \\ ${ }^{10}$ Department of Geology and Geophysics, Woods Hole Oceanographic Institution, \\ Woods Hole, MA 02543, USA \\ ${ }^{11}$ Institute of Geology and Geoinformation, National Institute of Advanced Industrial Science and \\ Technology (AIST), Tsukuba 305-8567, Japan \\ ${ }^{12}$ School of Geography, Earth and Environmental Sciences, University of Plymouth, Plymouth PL4 8AA, UK \\ ${ }^{13}$ Geosciences Montpellier, University of Montpellier, CNRS, Montpellier, France \\ ${ }^{14}$ Department of Earth and Planetary System Sciences, Hiroshima University, \\ Higashi-Hiroshima 739-8526, Japan \\ ${ }^{15}$ Research Institute of Earthquake and Volcano Geology, AIST, Tsukuba 305-8567, Japan \\ ${ }^{16}$ Department of Earth and Planetary Science, The University of Tokyo, Tokyo 113-0033, Japan \\ ${ }^{17}$ School of Earth and Space Exploration, Arizona State University, Tempe, AZ 85287-6004, USA \\ ${ }^{18}$ Mantle Drilling Promotion Office, Institute for Marine-Earth Exploration and Engineering (MarE3), \\ JAMSTEC, Yokohama 236-0001, Japan \\ Correspondence: Susumu Umino (sesumin@staff.kanazawa-u.ac.jp) \\ and Fumio Inagaki (inagaki@jamstec.go.jp)
}

Received: 23 November 2020 - Revised: 25 February 2021 - Accepted: 9 March 2021 - Published: 26 April 2021

Abstract. For more than half a century, exploring a complete sequence of the oceanic crust from the seafloor through the Mohorovičić discontinuity (Moho) and into the uppermost mantle has been one of the most challenging missions of scientific ocean drilling. Such a scientific and technological achievement would provide humankind with profound insights into the largest realm of our planet and expand our fundamental understanding of Earth's deep interior and its geodynamic behavior. The formation of new oceanic crust at mid-ocean ridges and its subsequent aging over millions of years, leading to subduction, arc volcanism, and recycling of some 
components into the mantle, comprise the dominant geological cycle of matter and energy on Earth. Although previous scientific ocean drilling has cored some drill holes into old ( $>110 \mathrm{Ma})$ and young $(<20 \mathrm{Ma})$ ocean crust, our sampling remains relatively shallow $(<2 \mathrm{~km}$ into intact crust) and unrepresentative of average oceanic crust. To date, no hole penetrates more than $100 \mathrm{~m}$ into intact average-aged oceanic crust that records the longterm history of seawater-basalt exchange (60 to $90 \mathrm{Myr}$ ). In addition, the nature, extent, and evolution of the deep subseafloor biosphere within oceanic crust remains poorly unknown. To address these fundamentally significant scientific issues, an international workshop "Exploring Deep Oceanic Crust off Hawai 'i” brought together 106 scientists and engineers from 16 countries that represented the entire spectrum of disciplines, including petrologists, geophysicists, geochemists, microbiologists, geodynamic modelers, and drilling/logging engineers. The aim of the workshop was to develop a full International Ocean Discovery Program (IODP) proposal to drill a $2.5 \mathrm{~km}$ deep hole into oceanic crust on the North Arch off Hawai' $i$ with the drilling research vessel Chikyu. This drill hole would provide samples down to cumulate gabbros of mature $(\sim 80 \mathrm{Ma})$ oceanic crust formed at a half spreading rate of $\sim 3.5 \mathrm{~cm} \mathrm{a}^{-1}$. A Moho reflection has been observed at $\sim 5.5 \mathrm{~km}$ below the seafloor at this site, and the workshop concluded that the proposed $2.5 \mathrm{~km}$ deep scientific drilling on the North Arch off Hawai' $\mathrm{i}$ would provide an essential "pilot hole" to inform the design of future mantle drilling.

\section{Introduction}

Sampling a complete section of the oceanic crust and upper mantle has been a primary goal of scientific ocean drilling since its inception with Project MoHole (National Research Council, 1957; Teagle and Ildefonse, 2011). However, despite more than a half century's effort, we have not yet managed to reach kilometers below the seafloor to the Mohorovičić discontinuity (Moho) and the underlying mantle. One of the technical difficulties of establishing a drill hole several kilometers deep is collapse of an uncased borehole, due to substantial lithostatic load and increasing temperatures. To prevent borehole collapse, riser-drilling technology is required for deep drilling to stabilize the borehole and remove cuttings. In 2005, the riser-drilling research vessel Chikyu was commissioned with the expressed ultimate goal of exploring the upper mantle (Umino et al., 2013). After 15 years of riser operations by the Chikyu, mantle drilling now comes into the realm of technical feasibility.

To accomplish arguably the most ambitious mission ever proposed in Earth sciences, we must appreciate two significant constraints: the capabilities of the riser-drilling system on the Chikyu and the lifetime of the vessel. The current Chikyu riser system using a blow-out preventer (BOP) and 21 in. standard riser pipes can be deployed at a maximum of $2500 \mathrm{~m}$ below sea level (m b.s.l.). Recent, albeit untested, technical investigations indicate that by using slimline, 16 in. riser pipes, riser operations could be extended to $\sim 4300 \mathrm{~m}$ b.s.l. The Chikyu is now 15 years into its operational life of 25 to 30 years. Consequently, it is imperative that the foundational steps for upper mantle drilling be initiated in the foreseeable future, such that drilling through the oceanic crust and into the upper mantle can be attempted during the operational lifetime of Chikyu.

Previous workshops have identified a limited number of sites globally where drilling intact ocean crust down into the mantle may be possible (Teagle and Ildefonse, 2011; Ildefonse et al., 2010); these include a relatively old site on the North Arch of the Hawaiian Islands. A seismic survey in support of future mantle drilling was conducted around the North Arch candidate site in 2017 through collaboration between the Japan Agency for Marine-Earth Science and Technology (JAMSTEC) and the University of Hawai' $i$ (Fig. 1). This survey revealed undisturbed primary structures of the Moho and the uppermost mantle around the proposed North Arch drill sites (Ohira et al., 2018). The SAKIGAKE-Japan Geoscience Union (JpGU) Hard Rock Drilling Focus Group Workshop was held in November 2018, Kanazawa, Japan, with participants from Japan, the USA, France, and Germany, to discuss the scientific rewards of drilling a complete section of upper oceanic crust on the North Arch of the Hawaiian Islands (Morishita et al., 2019).

IODP 951-Pre proposal "Drilling Middle Aged Oceanic Crust on North Arch off Hawai ' $\mathrm{P}$ " was submitted in April 2019 and reviewed by the IODP Science Evaluation Panel (SEP) in June 2019. IODP 951-Pre proposal proposed to drill a complete upper crustal section to the uppermost gabbros in $\sim 80 \mathrm{Ma}$ crust spread at $7-8 \mathrm{~cm} \mathrm{a}^{-1}$ on the North Arch off Hawai $i$, where flexure of oceanic lithosphere due to loading of the Hawaiian Islands has raised the seafloor to $\sim 4300 \mathrm{~m}$ b.s.l. due to the massive Hawaiian volcanoes (6$13 \mathrm{~km}$ tall) (Watts et al., 1985). The key advantages of this region relative to other MoHole candidates are its age and low heat flow $\left(\sim 55 \mathrm{~mW} \mathrm{~m}^{-2}\right)$ that predict relatively low temperatures at depth, and its relatively shallow Moho depth $(\sim 5.5$ to $6 \mathrm{~km}$ below seafloor). The estimated crustal temperatures $\left(<50^{\circ} \mathrm{C}\right.$ at $2 \mathrm{~km}$ and $<150^{\circ} \mathrm{C}$ at Moho depth) should diminish drilling and thermal stress-induced fracturing that has inhibited drilling in other deep holes (e.g., 5.9 Ma at Hole 504B and $15 \mathrm{Ma}$ at Hole 1256D).

In December 2019, an ancillary workshop "Scientific Ocean Drilling Off Hawai ‘i with Chikyu" was held in San 


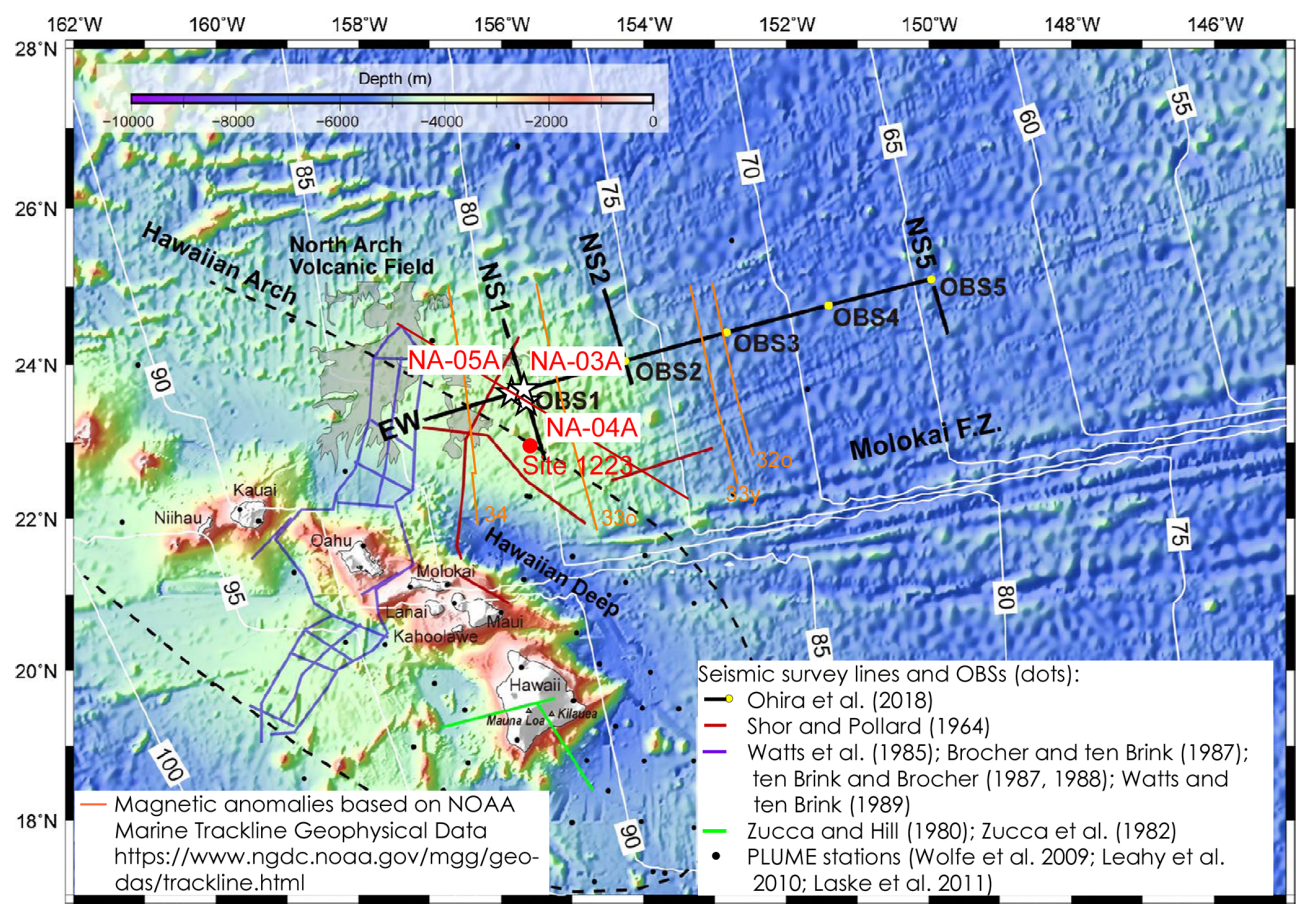

Figure 1. Proposed drill sites (primary site: NA-03A; alternative sites: NA-04A and NA-05A) and the bathymetry of the North Arch Volcanic Field (after Ohira et al., 2018). White lines with numbers are seafloor age (Ma) after Müller et al. (2008).

Francisco during the American Geophysical Union (AGU) Fall Meeting, where the updated information of the seismic analysis and other technological information related to the deep drilling off Hawai' $i$ were discussed. Given the discussion at the AGU ancillary workshop and SEP recommendation, the "Exploring Deep Oceanic Crust off Hawai' $i$ " workshop was organized to develop a 951-Full proposal in anticipation of future mantle drilling with Chikyu.

\section{Workshop structure}

The COVID-19 pandemic curtailed our initial plans for an early summer 2020 workshop in Honolulu, Hawai 'i. Instead, "Exploring Deep Oceanic Crust off Hawai 'i”" was held online from 29 June to 1 July 2020 . This $4 \mathrm{~d}$ virtual workshop engaged 106 registered participants from 16 countries (Fig. 2), following widespread advertisement through the Japan Drilling Earth Science Consortium (J-DESC), the U.S. Science Support Program (USSSP), the European Consortium for Ocean Research Drilling (ECORD) Science Operator (ESO), the Australian and New Zealand International Ocean Discovery Program Consortium (ANZIC), and JAMSTEC.

To take the time difference between participants in different parts of the world into account, each workshop day was subdivided into two $2 \mathrm{~h}$ sessions that covered different topics each day. A $2.5 \mathrm{~h}$ wrap-up plenary session was held on the final day. A web-based communication site was also established, where all participants could upload/download all of the workshop-relevant files. The breakout sessions on days 1,2 , and 3 were focused on the following respective themes: "Crustal Evolution: Alteration \& Aging" - discussion leaders: Takeshi Hanyu (JAMSTEC) and Damon Teagle (Univ. Southampton); "Crustal Architecture: Formation \& Deformation" - discussion leaders: Michael Garcia (Univ. Hawai'i) and Laura Crispini (Univ. Genoa); and "Water \& Deep Life" - discussion leaders: Fumio Inagaki (JAMSTEC) and Steven D'Hondt (Univ. Rhode Island). In each session, the discussion leader made a brief introduction, followed by a few invited presentations, flash-talks, and discussions of questions $(\mathrm{Q})$, hypotheses $(\mathrm{H})$, and approaches (A) appropriate to the session theme. On Day 4, the discussion leaders summarized the discussions, and the workshop co-chairs, Susumu Umino (Kanazawa Univ.) and Greg Moore (Univ. Hawai $\left.{ }^{(} i\right)$, summarized the outcomes and proposed consensus and action items towards building a compelling full proposal.

\section{Oceanic crustal architecture}

The formation of new oceanic crust at mid-ocean ridges, its subsequent aging and transformation over tens of million years, its eventual destruction in subduction zones, and its recycling through the Earth's mantle comprise the largest cycling of matter and energy on Earth. However, we are only beginning to comprehend the full diversity of oceanic crust; how it accretes along the $\sim 60000 \mathrm{~km}$ of mid-ocean ridges; 
(a)

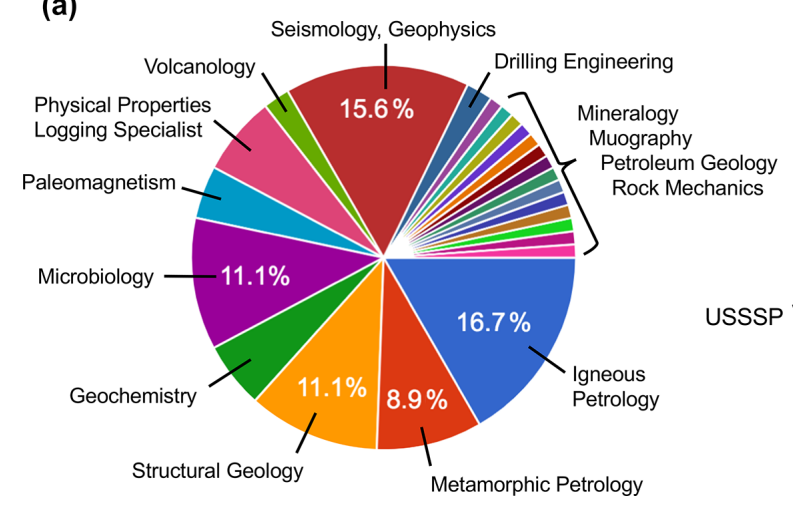

(b)

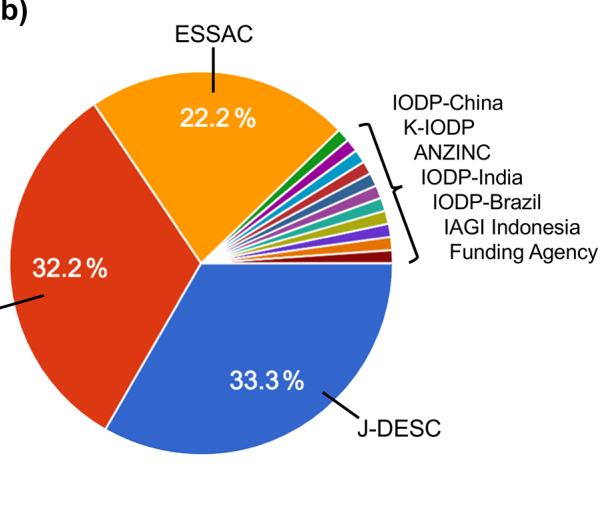

Figure 2. Statistics of the workshop participants. (a) Expertise of participants. (b) Locations of participants (based on the IODP Project Management Office and other information). The total number of registered participants was 106 from 16 nations.

in what manner it is chemically, physically, and biologically altered as it matures; and what fractions may be recycled in arcs or returned into the mantle.

Oceanic crust under the North Arch is a good candidate for understanding the physical, chemical, and biological evolution of mature oceanic lithosphere, as well as the effects of intraplate volcanism, and the regional history of hazardous landslides. Geological information from intact normal oceanic crust spread at $7-10 \mathrm{~cm} \mathrm{a}^{-1}$ is key to understanding the changes in style of upper crustal extension from fast to intermediate spreading rates. Scientific ocean drilling on the North Arch off Hawai' $i$ will help us to decipher the relationships between extension style, crustal architecture, deformation, and hydrothermal history of the crust. Drilling a $2.5 \mathrm{~km}$ deep pilot hole project using Chikyu will be the first tangible step toward achieving the ultimate goal of reaching the Moho.

Basic observations regarding the architecture of in situ present-day oceanic crust, including rock types, geochemistry, and thicknesses of the volcanic, dike, and plutonic sections, are yet to be made. It is a fundamental weakness of our knowledge of oceanic crust that we cannot yet relate seismic and magnetic imaging of the oceanic crust and geochemical inferences to basic geologic observations. We do not have a predictive understanding of the factors controlling thicknesses of seismic and geological layers in oceanic crust. This greatly precludes our ability to geologically interpret geophysical data or relate observations from drill holes to wider regional contexts.

The thickness of Layer 2 and the depth of axial magma chambers (AMC) show gradual increases with decreasing spreading rate from 22 to $10 \mathrm{~cm} \mathrm{a}^{-1}$. However, both parameters show very large ranges for spreading rates $<7 \mathrm{~cm} \mathrm{a}^{-1}$ (Christeson et al., 2019), indicating that crustal architecture fundamentally changes between spreading rates of 10 and $7 \mathrm{~cm} \mathrm{a}^{-1}$. The crust north of Hawai' $i$ spreads at $\sim 7 \mathrm{~cm} \mathrm{a}^{-1}$, which is at the lower end of this critical spreading rate interval. From available seismic data and current understand- ing, we predict a Layer 2 thickness at the proposed site of $\sim 1700$ to $2500 \mathrm{~m}$. Similarly, mapping of ridge-axis lava morphology also changes across this spreading rate interval. For crust spread at rates above $10 \mathrm{~cm} \mathrm{a}^{-1}$, the extrusive sequence is more than $70 \%$ sheet flows, whereas pillow lava dominates extrusives deposited at spreading rates below $7 \mathrm{~cm} \mathrm{a}^{-1}$ (see Morishita et al., 2019). Lava morphology is also affected by extrusion rate and basement slopes (Gregg and Fink, 1995; Umino et al., 2003). The profound change in dominant lava morphology at $7-10 \mathrm{~cm} \mathrm{a}^{-1}$ suggests that major changes in magma plumbing system and topography arise from changes in crustal architecture at the transition from fast- to intermediate-spreading rates. The spreading rate relationship predicts almost equal proportions of pillow and sheet flows among extrusive layers in the North Arch crust.

The geological meaning and physical causes of the transition from seismic Layer 2 to Layer 3 velocities remain poorly understood. In Hole 504B, the only place where the Layer $2-$ 3 transition has been penetrated in situ, this transition occurs near the middle of the $\sim 1 \mathrm{~km}$ thick sheeted dike complex. The transition to gabbroic rocks is at least $600 \mathrm{~m}$ deeper in the crust (Alt et al., 1993; Detrick et al., 1994). At Site 504, velocity gradient changes appear related to changes in the secondary hydrothermal mineralogy (Alt et al., 1996) and/or crack porosity (Carlson, 2010). The wider applicability of observations from intermediate-spreading-rate crust sampled in Hole 504B is yet to be tested. However, Hole 1256D reached gabbroic rocks, albeit at shallower levels, but still clearly within seismic Layer 2 (Gilbert and Salisbury, 2011).

The large $(800 \mathrm{~m})$ uncertainty in Layer 2 thickness (1700$2500 \mathrm{~m}$ ) off Hawai ' $i$ spans the ranges of the East Pacific Rise (EPR) and the Galapagos Spreading Center (GSC), precluding explicit conclusions. Considering the range in spreading rate (4.9-7.2 $\left.\mathrm{cm} \mathrm{a}^{-1}\right)$ along the entire GSC system, we may assume that the crust north of Hawai ' $i$ follows the GSC trend. Consequently, we predict $\sim 780 \pm 45 \mathrm{~m}$ thick extrusive sequence and $1320 \pm 440 \mathrm{~m}$ thick sheeted dikes, assuming the Layer 2A-2B boundary matches the extrusive-sheeted dike 

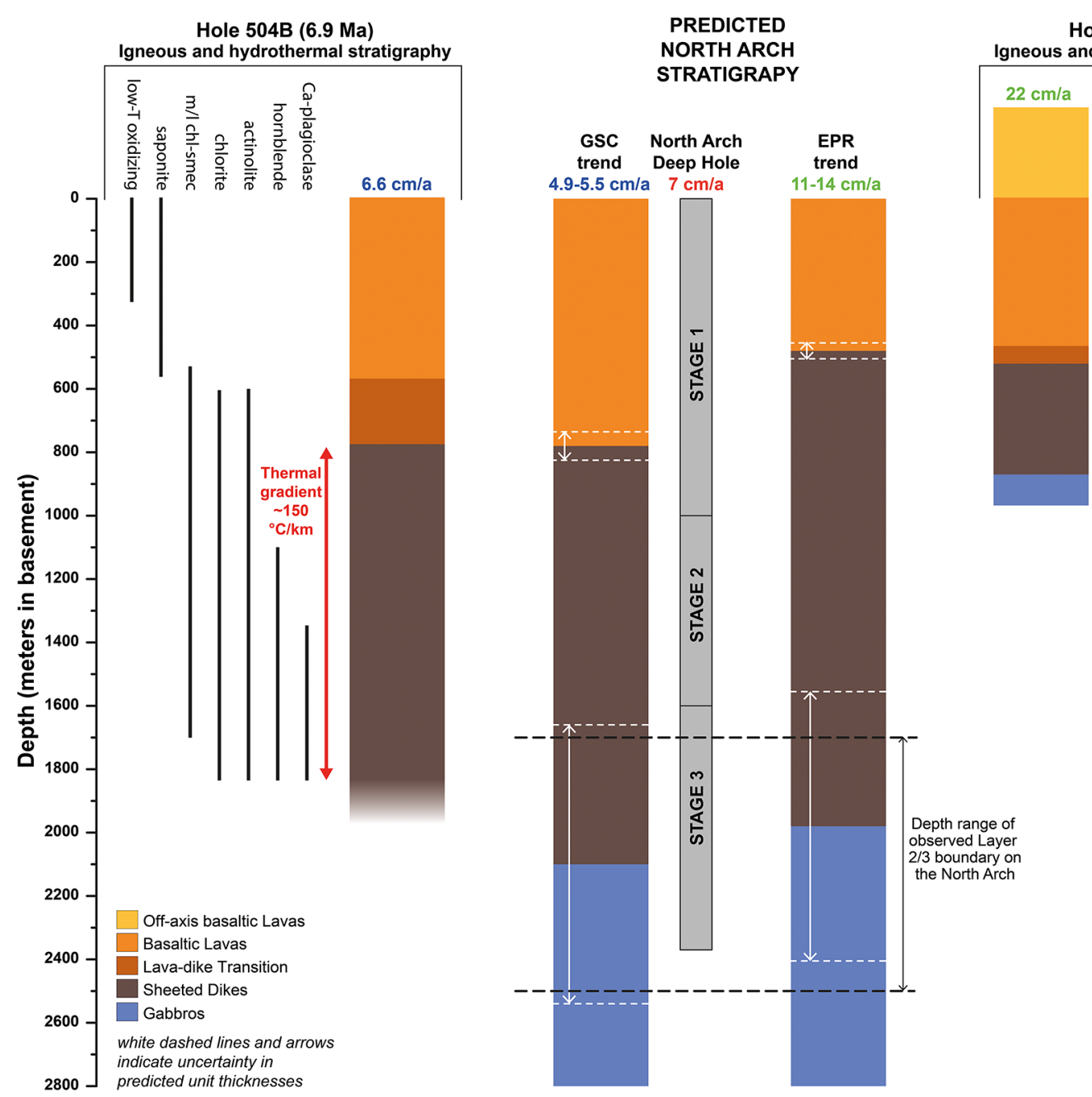

Hole 1256D (15 Ma)

Igneous and hydrothermal stratigraphy

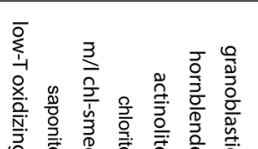

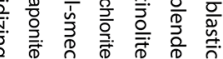

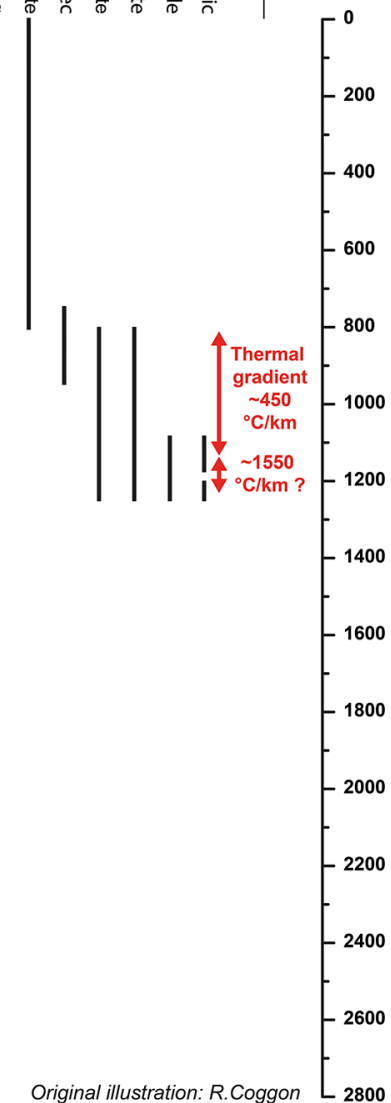

Figure 3. Holes 504B and 1256D rock type hydrothermal stratigraphies, and the predicted North Arch rock type stratigraphy (Phipps Morgan and Chen, 1993). The significantly different sheeted dike thicknesses at holes 504B and 1256D resulted in their dramatically different thermal

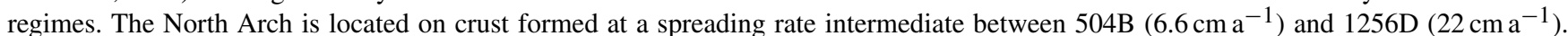
Distinct ocean crustal architectures are predicted on the basis of seismic observations from the Galapagos Spreading Center (GSC) and the East Pacific Rise (EPR). Given the North Arch spreading rate of $\sim 7 \mathrm{~cm} \mathrm{a}^{-1}$, we hypothesize that the crustal architecture will be similar to that predicted from the GSC trend. Holes 504B and 1256D stratigraphies and mineral distributions after Teagle et al. (2006).

transition (Fig. 3). The architecture of oceanic crust under the North Arch will be investigated by integrating wire-line logging and core observations to determine the stratigraphic variation of lithology and structures.

Primary hypothesis. The North Arch oceanic crust, formed at an intermediate spreading rate, comprises an intact 740-820 m thick sequence of about 50:50 pillow and sheet flows overlying a robust $880-1770 \mathrm{~m}$ thick sheeted dike complex.

The $2.5 \mathrm{~km}$ deep crustal drilling on the North Arch will drill though three major lithologic zones of the oceanic crust underlying $\sim 130 \mathrm{~m}$ thick sediments: basaltic lava, sheeted dike complex, and gabbros (Fig. 3). Core descriptions; detailed petrological, geochemical, 2D- and 3D-microstructural investigations; and wire-line logging observations will allow us to map hydrothermal pathways and fluid-rock exchanges through the crust, to examine the interactions between hydrothermal, magmatic, and tectonic processes that influence the architecture of the crust.

Drilling on the North Arch will allow us to evaluate the role that axial hydrothermal processes related to initial cooling and magma crystallization play in controlling melt distribution and tectonic deformation and, hence, oceanic crustal architecture. Importantly, hydrothermal alteration impacts the physical properties of oceanic crust and, therefore, complicates interpretation of regional geophysical data. Critically, understanding on/near-axis hydrothermal circulation requires a better knowledge of whether fluid flow on recharge and discharge paths is pervasive (grain boundary or small 
fractures) or is channeled by larger features (faults, pipes, or dikes) that concentrate thermal and chemical hydrothermal exchange. Thus, the following questions need to be answered:

- What is the role of lateral and vertical channeling on fluid flow and hydrothermal exchange?

- Is fluid flow focused by features such as boundaries between rock types, deformation zones, flow tops, and faults?

- What are the differences between measured permeability (porosity) and paleo-permeabilities (-porosities) and how would they affect fluid flow modeling?

\section{Hydrothermal alteration of mature oceanic crust}

The chemical and isotopic composition of seawater reflects the dynamic balance between riverine inputs from continents, burial of marine sediment, and hydrothermal exchanges with oceanic crust. Compared with continental crust, oceanic crust is young and chemically relatively homogeneous, and chemical exchanges with seawater are limited to a relatively few well-known reactions. Consequently, hydrothermal contributions to ocean chemistry are simpler to reconstruct than riverine inputs (Bickle and Teagle, 1992; Coogan, 2008; Coggon et al, 2010; Coggon and Teagle, 2011; Davis et al. 2003; Vance et al., 2009). Knowledge of the rates, depths, and magnitudes of low-temperature hydrothermal exchanges in aging oceanic crust would help us to decipher the changing global conditions responsible for past variations in seawater chemistry. Addressing these issues requires recovery of oceanic crust of different ages, from ridge flanks with different spreading and hydrogeologic histories.

Hydrothermally altered oceanic crust provides a record of geochemical exchange with seawater through changes in its chemical and isotopic composition, mineral assemblages, and physical properties (e.g., porosity, permeability, and seismic velocities). The intensity of this exchange reflects the complex interplay of seawater chemistry; the crust's age, spreading rate, thermal history, and accretion style; and the nature of the volcanic stratigraphy, availability of fluid pathways, basement topography and proximity of seamounts, as well as the sediment type, thickness, and accumulation rates that reflect the crust's journey across the seafloor. The recovered cores will improve our knowledge of the temporal and depth limits of chemical exchange across the aging ridge flanks. The analyses of cores will allow us to develop a more complete record of hydrothermal exchange between the ocean and oceanic crust and to better quantify the influence of the life cycle of tectonic plates on long-term biogeochemical cycling of key chemicals, including volatile species, such as noble gases, $\mathrm{H}_{2} \mathrm{O}, \mathrm{CO}_{2}, \mathrm{~N}_{2}, \mathrm{~S}, \mathrm{~B}$, and $\mathrm{Li}$, that we use to trace the evolution of our planet (e.g., Kendrick et al., 2017).
Extensive high-temperature hydrothermal exchanges $\left(>350^{\circ} \mathrm{C}\right)$ are necessarily associated with cooling and crystallization of magma at mid-ocean ridges, due to the great energy requirements for heating seawater to near critical-point temperatures or beyond. However, low- to moderate-temperature reactions are common, and they are principally driven by conductive heat from cooling of oceanic lithosphere and hydrological heads established by interaction of basement topography, relatively permeable zones within oceanic basement, and the extent and style of sediment cover. Whether these reactions continue throughout maturation of oceanic crust or are episodic remains poorly constrained. There is a discernible conductive heat flow anomaly out to an average of $\sim 65 \mathrm{Ma}$ (Stein and Stein, 1994), suggesting active advection of heat by fluid flow to this age. However, dating of secondary minerals recovered from oceanic crust suggests that most secondary minerals form within $20 \mathrm{Myr}$ of crustal formation (e.g., Coggon et al., 2010; Coogan et al., 2016). The question then arises as to whether heat could be advected by basement fluids without leaving a discernible chemical or mineralogical trace of this fluid flow?

The perception that secondary mineral formation is completed at relatively young crustal age, before the crust is thermally sealed, may reflect our sampling bias toward heavily sedimented crust. The proposed primary site is covered by only $\sim 110 \mathrm{~m}$ of sediment, $\sim 1 \sigma$ below the global average sediment thickness for $\sim 80$ Ma crust $(350 \pm 250 \mathrm{~m}$; Spinelli et al., 2004). The North Arch site provides a unique opportunity to investigate the timing and duration of ridge flank hydrothermal exchanges.

The importance of these issues is well illustrated by uncertainties regarding the uptake of $\mathrm{CO}_{2}$ by the oceanic crust (e.g., Alt and Teagle, 1999; Staudigel et al., 1989). Due to these uncertainties, it is unclear whether oceanic crust is a source or sink of $\mathrm{CO}_{2}$ in global geochemical cycles (Berner et al., 1983). Observations of oceanic crust sampled by drilling indicate that old crust $(>110 \mathrm{Ma})$ has a much higher carbonate content than young crust $(<15 \mathrm{Ma}$; see Alt and Teagle, 1999; Fig. 4). Is this difference related to progressive carbonization with age or the fact that carbonate uptake was relatively rapid in the Cretaceous and Paleogene reflecting seawater chemistry and conditions at the time of crustal formation? To answer this critical question, we must recover intermediate-age crust to determine its carbonate content, and when it was added to the crust. To address these scientific problems, we will deploy a combination of petrological and geochemical analyses, radiometric dating, and quantitative core-wire-line log integration of rock types, alteration features, and veins.

The second obstacle to developing a comprehensive record of hydrothermal exchange between the ocean and oceanic crust is our complete lack of samples from which to quantify the role of chemical exchange in deep oceanic crust older than $15 \mathrm{Ma}$. Previous models of the mantle volatile 

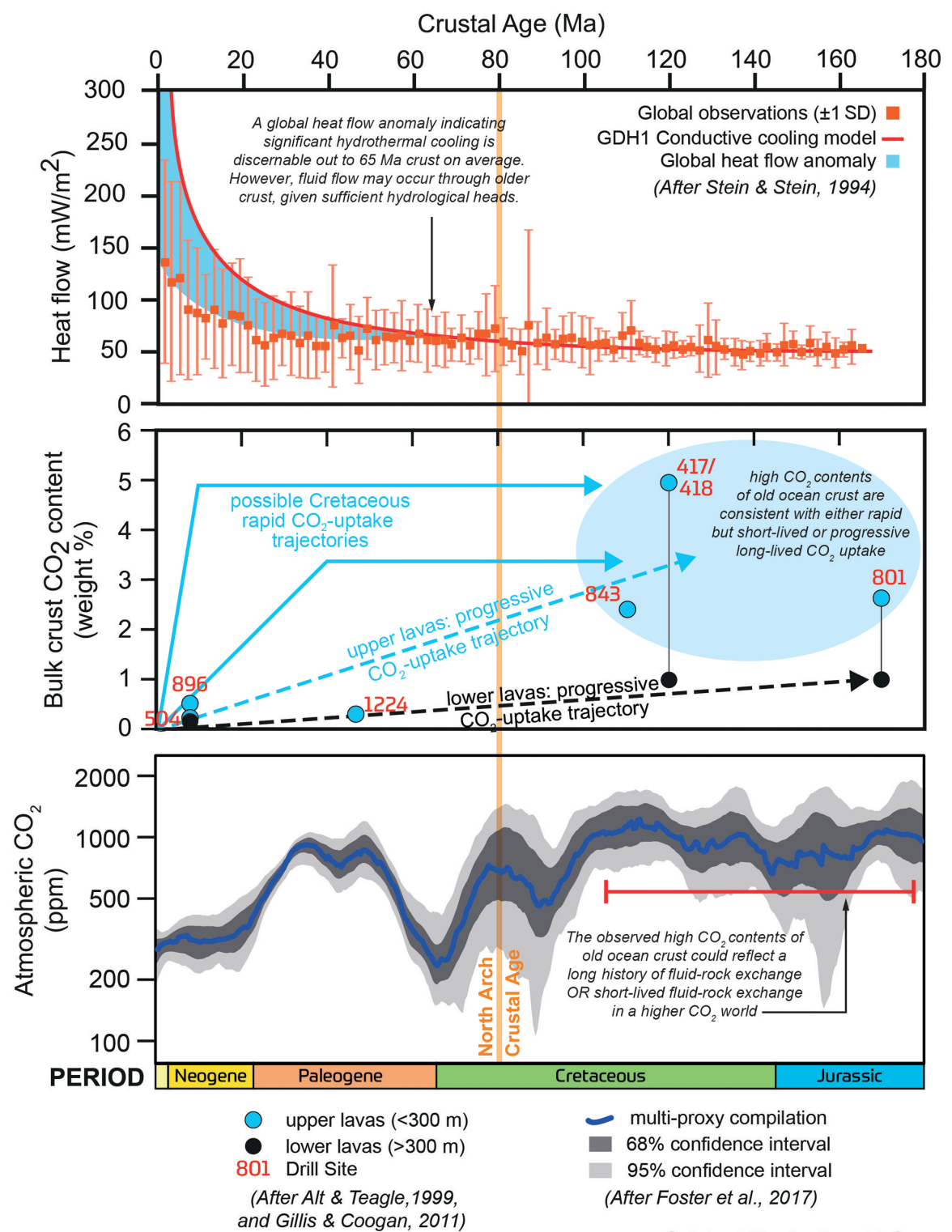

Original illustration: R. Coggon

Figure 4. Drilling into the $\sim 80 \mathrm{Ma}$ oceanic crust on the North Arch will allow us to determine what controls the duration and rate of $\mathrm{CO}_{2}$ uptake by the oceanic crust and to quantify the role of hydrothermal aging in the long-term global carbon cycle.

cycle assume low volatile concentrations in lower oceanic crust relative to upper crust (e.g., Dasgupta and Hirschmann, 2010). However, the concentrations of some important elements (e.g., B; see Sano et al., 2008) are much higher in the Hole $1256 \mathrm{D}$ dikes and gabbros than previously estimated, indicating deeper exchange with seawater-derived hydrothermal fluids.

Much of our current knowledge comes from ophiolites, which are ancient blocks of oceanic crust preserved on land (e.g., Gregory and Taylor, 1981; Coggon et al., 2016). However, many of the best studied ophiolite massifs, such as Troodos or Oman, formed in complex supra-subduction zone settings. Consequently, observations from ophiolites remain controversial and poorly tested by observations from intact oceanic crust. Where dikes and gabbros are exposed in ophiolites they commonly display abundant veining and bulkrock alteration to sub-greenschist and zeolite facies assemblages (e.g., prehnite, quartz, chlorite-smectite, laumontite, and other zeolites \pm carbonates; see Kelemen et al., 2020). These assemblages overprint higher temperature background and channeled hydrothermal alteration (e.g., amphibole and epidote veins) that relate to active hydrothermal circulation, but their absolute timing is difficult to determine. Consequently, whether these phases record deep, off-axis hydrothermal exchanges or fluid-rock reactions specific to emplacement of the ophiolite remains unresolved. 
The sub-greenschist to zeolite assemblages in the dikes and gabbros from holes 504B and 1256D are not present to the same extents/styles as in ophiolites. It is most commonly assumed that high-temperature mineral precipitation in dikes and gabbros restricts off-axis fluid flow to more fractured and/or brecciated zones within the volcanic series, with fluid flow driven by heat conduction from the lithosphere below. However, deep off-axis penetration of seawater-derived hydrothermal fluid is possible, either pervasively or, more likely, channeled along specific conduits such as faults. These hypothetical reactions may occur between deep, relatively fresh diabase and gabbro at low to moderate temperatures $\left(<150^{\circ} \mathrm{C}\right)$ and could provide energy and nutrients for hitherto unrecognized deep microbial communities and additional unquantified fluid-rock exchanges between seawater and oceanic crust. The deep $(\sim 2500 \mathrm{~m}$ subbasement) hole on the North Arch will complement observations from the younger holes 504B and 1256D and test the applicability of ideas and quantifications developed from ophiolites.

Primary hypothesis. Hydrothermal exchanges between the oceanic crust and seawater are episodic, not continuous. Consequently, the extent of fluid-rock exchange does not just depend on age of the oceanic crust but also depends on external factors that enhance fluid flow and reaction. As a result, there may not be simple relationships between crustal age, fluid flow, thermal and chemical exchange, and biological activity.

The proposed North Arch drilling project will recover, for the first time, sheeted dikes and upper gabbros in mature crust $(>15 \mathrm{Ma}$ ) that has experienced the full range of fluid-rock exchanges that occur over a significant period that would be representative of typical oceanic crust before it is subducted in the western Pacific. These observations will provide a unique opportunity to develop a more complete record of hydrothermal exchange between the ocean and oceanic crust.

\section{Nature and extent of life in the oceanic crust}

The samples and data from the drilling project on the North Arch will address the physical and chemical limits of subseafloor life. This project will determine the extents to which microbial communities colonize and persist in successively deeper layers of volcanic extrusive rocks, dikes, and upper gabbroic basement in oceanic crust, and in complex transition zones between these layers. The frequency of encountering microbial communities within the recovered rock will illuminate the ease by which they disperse and find new resources. The project will identify the diversity and compositions of these communities; it will illuminate their origin by testing their phylogenetic relationships to microbes in the overlying sediment and in the surface world; and it will ad- vance understanding of the mechanisms that they use to generate energy and fix carbon far from the influence of Earth's surface (photosynthetic) environments. The expected results will clarify their global significance by examining relationships between their capabilities and the alteration histories of their habitats.

Previous scientific ocean drilling has demonstrated that bacteria, archaea, fungi, and viruses inhabit marine sediment (D'Hondt et al., 2004; Inagaki et al., 2006, 2015; Orsi et al., 2013; Engelhardt et al., 2014; Liu et al., 2017; Hoshino et al., 2020) and the shallow basaltic aquifer that underlies marine sediment (Cowen et al., 2003; Lever et al., 2013; Ivarsson et al., 2016; Jørgensen and Zhao, 2016; Nigro et al., 2017; Quemener et al., 2020; Suzuki et al., 2020). A few studies have reported evidence of microbial communities in North Atlantic gabbroic lower crust exposed by faulting (Alt et al., 2007; Mason et al., 2010; Li et al., 2020). As there are no studies of microbial communities from gabbros in intact crust overlain by extrusive and dike sequences, it is not clear if these fault-exposed communities are indigenous to normal lower crust or were locally introduced from the ocean via fluid circulation in faulted near-seafloor sequences.

Secondary mineralization is ubiquitous in oceanic crust. Different minerals precipitate at different stages in crustal evolution, as temperature declines and fluid-flow paths evolve and become restricted. For example, celadonite and iron oxyhydroxides precipitate at low temperatures in young crust, whereas calcite and zeolite tend to precipitate relatively late in the alteration sequence (Alt, 1995; Alt and Teagle, 1999). Temperature typically decreases with crustal age but increases with depth in crust. As a result, secondary minerals at greater crustal depths (e.g., albite, chlorite, and epidote in the sheeted dikes) precipitate at much higher temperatures than the minerals at shallow depths (in the extrusive volcanics) (Alt, 1995). As crust cools with age, the zone of low-temperature mineralization may migrate downward to depths previously characterized by high-temperature mineralization. However, this has not yet been tested in mature intact oceanic crust.

Recent studies reported that microbes are abundant in specific secondary minerals in shallow cores $(<100 \mathrm{~m})$ into old (33.5-104 Ma), cold crust of the South Pacific (Suzuki et al., 2020) (Fig. 5). The microbes are associated with iron-rich smectite at interfaces between basalt wall-rocks and celadonite + iron oxyhydroxide veins. The microbebearing smectites are late-stage secondary minerals associated closely with early-stage minerals (celadonite, iron oxyhydroxide). The crust age of the oldest South Pacific samples $(104 \mathrm{Ma})$ is $\sim 24 \mathrm{Ma}$ older than the drill site on the North Arch, underscoring the potential for direct detection of microbes in mineral-filled veins in deeper realms. Coring the successive layers of upper oceanic crust at the North Arch site (extrusives, dikes, upper gabbro) will provide a unique opportunity to determine how deeply microbial communities penetrate into mature oceanic crust. 

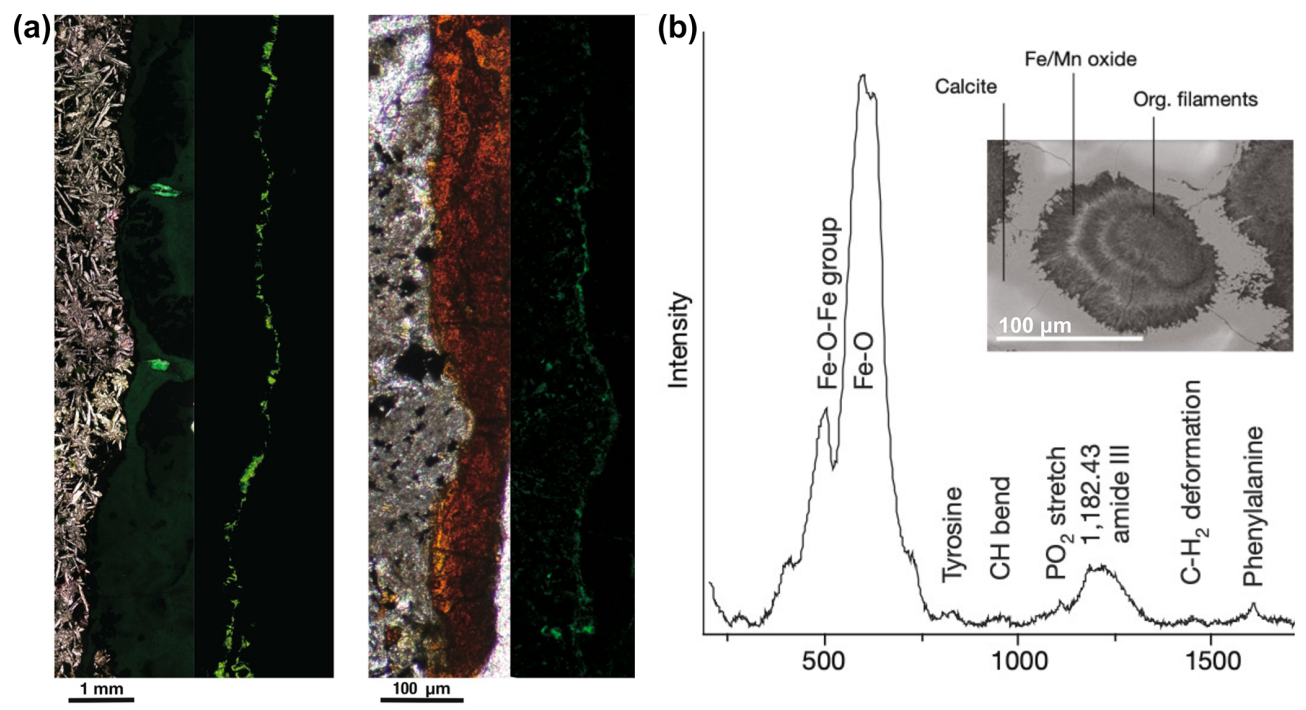

Figure 5. (a) Abundant microbes in secondary minerals (smectite) at basalt-mineral interfaces from IODP Hole U1365E. Light and fluorescence microscopy images of SYBR Green I-stained microbial cells in a fracture filled with celadonite from U1365E-8R4 and a vein filled with iron oxyhydroxides from Site U1365E-12R2 (Suzuki et al., 2020). (b) Confocal Raman analysis of organic inclusions in calcite from Atlantis Bank (fault-exhumed lower crust), IODP Hole 1473A (Li et al., 2020).

The distributions, compositions, activities, and biogeochemical consequences of microbial communities in oceanic crust are largely unknown. It is not known if microbial colonies persist on the basement surface after burial by sediment. Most importantly, nothing is known about the presence or absence, environmental associations, characteristics, or consequences of microbial communities in the intrusive dikes or gabbroic crust beneath intact extrusive sequences. Relationships of habitats and communities in the shallow extrusive sequence to habitats and communities (if present) in the deeper volcanic rocks, the underlying dikes, and the gabbros below are completely unknown.

Relationships between microbes in the extrusive crust and microbes in the overlying sediment are poorly understood (Labonté et al., 2017). Associations between minerals and microbial occurrences in subseafloor sediment are unexamined. Thus, this poses the following question: are similar microbes associated with similar minerals in both crust and sediment? In both sediment and crust, whether the habitat is oxic or anoxic appears to set a fundamental constraint on both community composition and dominant microbial activities. Anoxic environments are characterized by anaerobic communities and activities, whereas oxic subseafloor environments are characterized by aerobic communities and activities (Cowen et al., 2003; Huber et al., 2006; Meyer et al., 2016; Tully et al., 2018).

The metabolic activities that sustain microbial communities in shallow crust are poorly constrained. Potential consequences of those activities include chemical alteration of the crust, precipitation of secondary minerals, and microbially induced fracture filling. To the extent that they mediate these processes, crustal communities shape the chemical composition of the ocean and crust, as well as the physical structure of the crust (Thorseth et al., 1995; Bach and Edwards, 2003; D'Hondt et al., 2019).

Processes that might support life in oceanic crust include oxidation of (i) reduced elements in the crust, (ii) dissolved organic matter (DOM) that enters with seawater (ShahWalter et al., 2018), abiotic organic matter and/or $\mathrm{H}_{2}$ from serpentinization (Klein et al., 2015; Ménez et al., 2018; Majumdar et al., 2020), (iii) fault-induced (mechanically produced) $\mathrm{H}_{2}$ production, and (iv) $\mathrm{H}_{2}$ from in situ water radiolysis (D'Hondt et al., 2019). All of these processes require oxidants, which can be dissolved chemicals $\left(\mathrm{O}_{2}, \mathrm{NO}_{3}^{-}, \mathrm{SO}_{4}^{2-}\right)$ carried by diffusion or flow of seawater into the subseafloor, oxidized elements in minerals, and oxidants created by water radiolysis (e.g., $\mathrm{H}_{2} \mathrm{O}_{2}$ ) (D'Hondt et al., 2019).

It seems likely, although untested, that the metabolic importance of these processes changes with crust depth; seawater DOM is likely to disappear with increasing depth, whereas $\mathrm{H}_{2}$ and $\mathrm{CH}_{4}$ produced by serpentinization (Majumdar et al., 2020; Klein et al., 2019) and transported from greater depth may appear with increasing depth. Radiolytic $\mathrm{H}_{2}$ and radiolytic oxidants (Dzaugis et al., 2016) may increase in metabolic importance as fluxes of DOM and oxidants from seawater decrease with increasing depth. The relative importance of these processes is likely to depend on crust permeability and void connectivity; deep off-axis penetration of seawater-derived hydrothermal fluid could be pervasive or channeled along faults. Resultant oxidation of diabase, gabbro, and mineral-bound abiotic organic matter at low temperatures $\left(<150{ }^{\circ} \mathrm{C}\right)$ could help to sustain microbial 
communities in the dikes and gabbroic crust deep beneath the ocean.

Primary hypothesis. In mature oceanic crust cooler than the thermal limit to life, water-rock interactions sustain microbial life as deeply as seawater-derived fluid penetrates.

Coring the successive layers of sediment and upper oceanic crust to gabbro at the North Arch site will provide a unique opportunity to determine how compositions and activities of microbial communities change with depth in mature oceanic crust, in response to lithologic boundaries, and/or physical and chemical conditions. Because contamination of rock surfaces by microbes is ubiquitous in hardrock drilling, we will particularly focus on searching for microbial communities and biosignatures within vein-filling minerals (e.g., Suzuki et al., 2020).

\section{Conclusion}

During the virtual workshop "Exploring Deep Oceanic Crust off Hawai 'i”, we discussed how, through scientific drilling, we would investigate the physical, chemical, and biological architecture and evolution of the ocean crust to test three major hypotheses: (1) the North Arch crust spread at an intermediate rate will comprise an intact 500-800 m thick extrusive sequence with equal proportions of pillow and sheet flows, overlying a thick (1300-1600 m) sheeted dike complex; (2) hydrothermal exchanges between the ocean crust and seawater are episodic, and the extent of fluid-rock exchange does not just reflect the age of the crust but external factors that enhance fluid flow and reaction; and (3) in ocean crust cooler than the thermal limit to life, water-rock interactions sustain microbial life as deeply as seawater-derived fluid penetrates. In addition, scientific drilling will provide insights into North Arch volcanism and hazardous giant landslides from the Hawaiian volcanoes. Consequently, the major objectives during the $2.5 \mathrm{~km}$ deep crustal drilling on the North Arch will be to

- determine the structure and petrology of the extrusive lavas, sheeted dike complex, upper gabbros, and their correlations with seismic layers, specifically the nature of the Layer 2-3 transition;

- investigate the history of deformation and its relationships to spreading, and hydrothermal fluid-flow;

- evaluate the nature of the conductive thermal boundary layer between the axial magmatic chamber and the overlying sheeted dikes and make the first direct observations of the uppermost cumulate rocks;

- evaluate the extent and mode of tectonic disturbance and geochemical alteration by flexure of mature Pacific lithosphere and North Arch volcanism;
- determine a longer-term sedimentary record of giant landslides;

- compare hydrothermal alteration of mature $(\sim 80 \mathrm{Ma})$ intact ocean crust with younger (e.g., holes 504B, 1256D) and older (e.g., Hole 801C), and slow-spreading crust (e.g., IODP Expeditions 390/393 South Atlantic Transect);

- determine the nature, relative timing and absolute ages, and formation temperatures of successive alteration minerals, and quantify the extents of hydrothermal exchanges for fluid-mobile elements and volatiles;

- determine the depth limit of low-temperature hydrothermal alteration and quantify the associated chemical exchange;

- investigate the compositions and the extent of microbial communities in vein-filling secondary minerals in the deeper crust and their phylogenetic relationships to microbes in the overlying sediment and in the surface world;

- identify relationships between in situ metabolic gene expression, microbial capabilities under experimental conditions, alteration history, and physical/chemical gradients from the sediment-crust interface to the upper gabbros.

These overarching scientific objectives are strongly connected, and progress on each objective is tightly related to progress on the others.

During this workshop, the participants agreed that the $2.5 \mathrm{~km}$ deep drilling project on the North Arch off Hawai' $i$ should be placed as a "pilot hole" to inform the design of a future MoHole and gain experience in deep hard-rock drilling with Chikyu. Participants also agreed that the action will be a cornerstone project that contributes to the Flagship Initiatives "2. Probing the Deep Earth" and "5. Exploring Life and Its Origins" in the 2050 Science Framework (Koppers and Coggon, 2020).

Data availability. No data sets were used in this article.

Author contributions. SU and GFM co-chaired the workshop. NA, NX, YY, and FI organized the workshop. LC, SD'H, MOG, TH, DAHT, and FI led breakout sessions as the discussion leaders. SU, GFM, BB, RC, LC, SD'H, MOG, TH, FK, NS, DAHT, MT, MY, MH, BI, IK, YK, YS, ETR, and YY contributed to IODP 951Full proposal development as the proponent. SU, GFM, RC, LC, SD'H, MOG, TH, NS, DAHT, NX, YY, and FI co-wrote the paper with input from all co-authors.

Competing interests. The authors declare that they have no conflict of interest. 
Acknowledgements. The authors are grateful to all participants of the virtual workshop "Exploring Deep Oceanic Crust off Hawai ' $i$ " for their extensive discussions and useful comments. We also wish to thank J-DESC, USSSP, ESO, ANZIC, and JAMSTEC for this workshop. The authors acknowledge Gary Acton, Stephen Bowden, Gail Christeson, Virginia Edgcomb, Mark Kendrick, Jürgen Koepke, Mark A. Lever, Takashi Sano, Man-Yin Tsang, Hiroyuki Tanaka, and Dezso Varga for their presentations during the workshop, and Tomokazu Saruhashi and the JAMSTEC fleet operation team for the operational advice on the Chikyu.

Review statement. This paper was edited by Will Sager and reviewed by Jeffrey Alt and Jörg Geldmacher.

\section{References}

Alt, J. C. and Teagle, D. A. H.: The uptake of carbon during alteration of ocean crust, Geochim. Cosmochim. Ac., 63, 1527-1535, https://doi.org/10.1016/S0016-7037(99)00123-4, 1999.

Alt, J. C.: Subseafloor Processes in Mid-Ocean Ridge Hydrothennal Systems, Seafloor Hydrothermal Systems: Physical, Chemical, Biological, and Geological Interactions, 91, 85-114, https://doi.org/10.1029/GM091p0085, 1995.

Alt, J. C., Kinoshita, H., Stokking, L. B., and Shipboad Scientific Party: Initial Reports, College Station, TX (Ocean Drilling Program), Proc. ODP, Init. Repts., 148, https://doi.org/10.2973/odp.proc.ir.148.1993, 1993.

Alt, J. C., Kinoshita, H., Stokking, L. B., and Michael, P. J. (Eds.): Scientific Results, College Station, TX (Ocean Drilling Program), Proc. ODP, Sci. Results, 148, https://doi.org/10.2973/odp.proc.sr.148.1996, 1996.

Alt, J. C., Shanks, W. C., Bach, W., Holger, P., Garrido, C. J., and Beaudoin, G.: Hydrothermal alteration and microbial sulfate reduction in peridotite and gabbro exposed by detachment faulting at the Mid-Atlantic Ridge, $15^{\circ} 20^{\prime} \mathrm{N}$ (ODP Leg 209): A sulfur and oxygen isotope study, Geochem. Geophy. Geosy., 8, Q08002, https://doi.org/10.1029/2007GC001617, 2007.

Bach, W. and Edwards, K. J.: Iron and sulfide oxidation within the basaltic ocean crust: implications for chemolithoautotrophic microbial biomass production, Geochim. Cosmochim. Ac., 67, 3871-3887, https://doi.org/10.1016/S0016-7037(03)00304$1,2003$.

Berner, R. A., Lasaga, A. C., and Garrels, R. M.: The carbonatesilicate geochemical cycle and its effect on atmospheric carbon dioxide over the past 100 million years, Am. J. Sci., 283, 641683, https://doi.org/10.2475/ajs.283.7.641, 1983.

Bickle, M. J. and Teagle, D. A. H.: Strontium alteration in the Troodos ophiolite: implications for fluid fluxes and geochemical transport in mid-ocean ridge hydrothermal systems, Earth Planet. Sc. Lett., 113, 219-237, https://doi.org/10.1016/0012821X(92)90221-G, 1992.

Brocher, T. M. and ten Brink, U. S.: Variations in oceanic layer 2 elastic velocities near Hawaii and their correlation to lithospheric flexure, J. Geophys. Res.-Atmos., 92, 2647-2661, https://doi.org/10.1029/JB092iB03p02647, 1987.

Carlson, R. L.: How crack porosity and shape control seismic velocities in the upper oceanic crust: Modeling downhole logs from
Holes 504B and 1256D, Geochem. Geophy. Geosy., 11, Q04007, https://doi.org/10.1029/2009GC002955, 2010.

Christeson, G. L., Goff, J. A., and Reece, R. S.: Synthesis of oceanic crustal structure from two-dimensional seismic profiles, Rev. Geophys., 57, 504-529, https://doi.org/10.1029/2019RG000641, 2019.

Coggon, R. M. and Teagle, D. A. H.: Hydrothermal calcium-carbonate veins reveal past ocean chemistry, TrAC-Trend. Anal. Chem., 30, 1252-1268, https://doi.org/10.1016/j.trac.2011.02.011, 2011.

Coggon, R. M., Teagle, D. A. H., Smith-Duque, C. E., Alt, J. C., and Cooper, M. J.: Reconstructing past seawater $\mathrm{Mg} / \mathrm{Ca}$ and $\mathrm{Sr} / \mathrm{Ca}$ from mid-ocean ridge flank calcium carbonate veins, Science, 327, 1114-1117, https://doi.org/10.1126/science.1182252, 2010.

Coggon, R. M., Teagle, D. A. H., Harris, M., Davidson, G. J., Alt, J. C., and Brewer, T. S.: Hydrothermal contributions to global biogeochemical cycles: Insights from the Macquarie Island ophiolite, Lithos, 264, 329-347, https://doi.org/10.1016/j.lithos.2016.08.024, 2016.

Coogan, L. A.: Reconciling temperatures of metamorphism, fluid fluxes, and heat transport in the upper crust at intermediate to fast spreading mid-ocean ridges, Geochem. Geophy. Geosy., 9 Q02013, https://doi.org/10.1029/2007GC001787, 2008.

Coogan, L. A., Parrish, R. R., and Roberts, N. M. W.: Early hydrothermal carbon uptake by the upper oceanic crust: Insight from in situ U-Pb dating, Geology, 44, 147-150, https://doi.org/10.1130/G37212.1, 2016.

Cowen, J. P., Giovannoni, S. J., Kenig, F., Johnson, H. P., Butterfield, D., Rappé, M. S., Hutnak, M., and Lam, P.: Fluids from aging ocean crust that support microbial life, Science, 299, 120 123, https://doi.org/10.1126/science.1075653, 2003.

Dasgupta, R. and Hirschmann, M. M.: The deep carbon cycle and melting in Earth's interior, Earth Planet. Sc. Lett., 298, 1-13, https://doi.org/10.1016/j.epsl.2010.06.039, 2010.

Davis, A. C., Bickle, M. J., and Teagle, D. A. H.: Imbalance in the oceanic strontium budget, Earth Planet. Sci. Lett., 211, 173-187, https://doi.org/10.1016/S0012-821X(03)00191-2, 2003.

Detrick, R., Collins, J., Stephen, R., and Swift, S.: In situ evidence for the nature of the seismic layer $2 / 3$ boundary in oceanic crust Nature, 370, 288-290, https://doi.org/10.1038/370288a0, 1994.

D’Hondt, S., Jørgensen, B. B., Miller, D. J., Batzke, A., Blake, R., Cragg, B. A., Cypionka, H., Dickens, G. R., Ferdelman, T., Hinrichs, K-U., Holm, N. G., Mitterer, R., Spivack, A., Wang, G., Bekins, B., Engelen, B., Ford, K., Gettemy, G., Rutherford, S D., Sass, H., Skilbeck, C. G., Aiello, I. W., Guerin, G., House, C., Inagaki, F., Meister, P., Naehr, T., Niitsuma, S., Parkes, R. J., Schippers, A., Smith, D. C., Teske, A., Wiegel, J., Padilla, C. N., and Acosta, J. L. S.: Distributions of metabolic activities in deep subseafloor sediments, Science, 306, 2216-2201, https://doi.org/10.1126/science.1101155, 2004.

D'Hondt, S., Pockalny, R., Fulfer, V. M., and Spivack, A. J.: Subseafloor life and its biogeochemical impacts, Nat. Commun., 10, 3519, https://doi.org/10.1038/s41467-019-11450-z, 2019.

Dzaugis, M. E., Spivack, A. J., Dunlea, A. G., Murray, R. W., and D'Hondt, S.: Radiolytic hydrogen production in the subseafloor basaltic aquifer, Front. Microbiol., 7, 76, https://doi.org/10.3389/fmicb.2016.00076, 2016.

Engelhardt, T., Kallmeyer, J., Cypionka, H., and Engelen, B.: High virus-to-cell ratios indicate ongoing production of 
viruses in deep subsurface sediments, ISME J,, 8, 1503-1509, https://doi.org/10.1038/ismej.2013.245, 2014.

Gilbert, L. A. and Salisbury, M. H.: Oceanic crustal velocities from laboratory and logging measurements of Integrated Ocean Drilling Program Hole 1256D, Geochem. Geophy. Geosy., 12, Q09001, https://doi.org/10.1029/2011GC003750, 2011.

Gregg, T. K. P. and Fink, J. H.: Quantification of submarine lava-flow morphology through analog experiments, Geology, 23, 73-76, https://doi.org/10.1130/00917613(1995)023<0073:QOSLFM>2.3.CO;2, 1995.

Gregory, R. T. and Taylor, H. P.: An oxygen isotope profile in a section of Cretaceous oceanic crust, Samail Ophiolite, Oman: Evidence for $\delta^{18} \mathrm{O}$ buffering of the oceans by deep $(>5 \mathrm{~km})$ seawater-hydrothermal circulation at midocean ridges, J. Geophys. Res.-Sol. Ea., 86, 2737-2755, https://doi.org/10.1029/JB086iB04p02737, 1981.

Hoshino, T., Doi, H., Uramoto, G.-I., Wömer, L., Adhikari, R. R., Xiao, N., Morono, Y., D'Hondt, S., Hinrichs, K.-U., and Inagaki, F.: Global diversity of microbial communities in marine sediment, P. Natl. Acad. Sci. USA, 117, 27587-27597, https://doi.org/10.1073/pnas.1919139117, 2020.

Huber, J. A., Johnson, H. P., Butterfield, D. A., and Baross, J. A.: Microbial life in ridge flank crustal fluids, Environ. Microbiol., 8, 88-99, https://doi.org/10.1111/j.1462-2920.2005.00872.x, 2006.

Ildefonse, B., Abe, N., Blackman, D. K., Pablo Canales, J., Isozaki, Y., Kodaira, S., Myers, G., Nakamura, K., Nedimovic, M., Skinner, A. C., Seama, N., Takazawa, E., Teagle, D. A. H., Tominaga, M., Umino, S., Wilson, D. S., and Yamao, M.: The MoHole: A Crustal Journey and Mantle Quest, Workshop in Kanazawa, Japan, 3-5 June 2010, Sci. Dril., 10, 56-63, https://doi.org/10.2204/iodp.sd.10.07.2010, 2010.

Inagaki, F., Nunoura, T., Nakagawa, S., Teske, A., Lever, M., Lauer, A., Suzuki, M., Takai, K., Delwiche, M., Colwell, F. S., Nealson, K. H., Horikoshi, K., D’Hondt, S., and Jørgensen, B. B.: Biogeographical distribution and diversity of microbes in methane hydrate-bearing deep marine sediments on the Pacific Ocean Margin, P. Natl. Acad. Sci. USA, 103, 2815-2820, https://doi.org/10.1073/pnas.0511033103, 2006.

Inagaki, F., Hinrichs, K.-U., Kubo, Y., Bowles, M. W., Heuer, V. B., Hong, W.-L., Hoshino, T., Ijiri, A., Imachi, H., Ito, M., Kaneko, M., Lever, M. A., Lin, Y.-S., Methé, B. A., Morita, S., Morono, Y., Tanikawa, W., Bihan, M., Bowden, S. A., Elvert, M., Glombitza, C., Gross, D., Harrington, G. J., Hori, T., Li, K., Limmer, D., Liu, C.-H., Murayama, M., Ohkouchi, N., Ono, S., Park, Y.-S., Phillips, S. C., Prieto-Mollar, X., Purkey, M., Riedinger, N., Sanada, Y., Sauvage, J., Snyder, G., Susilawati, R., Takano, Y., Tasumi, E., Terada, T., Tomaru, H., Trembath-Reichert, E., Wang, D. T., and Yamada, Y.: Exploring deep microbial life down to $\sim 2.5 \mathrm{~km}$ below the ocean floor, Science, 349, 420-424, https://doi.org/10.1126/science.aaa6882, 2015.

Ivarsson, M., Bengtson, S., and Neubeck, A.: The igneous oceanic crust - Earth's largest fungal habitat?, Fungal Ecol., 20, 249-255, https://doi.org/10.1016/j.funeco.2016.01.009, 2016.

Jørgensen, S. L. and Zhao, R.: Microbial inventory of deeply buried oceanic crust from a young ridge flank, Front. Microbiol., 7, 820, https://doi.org/10.3389/fmicb.2016.00820, 2016.

Kelemen, P. B., Matter, J. M., Teagle, D. A. H., Coggon, J. A., and the Oman Drilling Project Science Team: College Station, TX (International Ocean Discovery
Program), Proceedings of the Oman Drilling Project, https://doi.org/10.14379/OmanDP.proc.2020, 2020.

Kendrick, M. A., Hemond, C., Kamenetsky, V. S., Danyushevsky, L., Devey, C. W., Rodemann, T., Jackson, M. G., and Perfit, M. R.: Seawater cycled throughout Earth's mantle in partially serpentinized lithosphere, Nat. Geosci., 10, 222-228, https://doi.org/10.1038/ngeo2902, 2017.

Klein, F., Humphris, S. E., Guo, W., Schubotz, F., Schwarzenbach, E. M., and Orsi W. D.: Fluid mixing and the deep biosphere of a fossil Lost City-type hydrothermal system at the Iberia Margin, P. Natl. Acad. Sci. USA, 112, 12036-12041, https://doi.org/10.1073/pnas.1504674112, 2015.

Klein, F., Grozeva, N. G., and Seewald, J. S.: Abiotic methane synthesis and serpentinization in olivine-hosted fluid inclusions, P. Natl. Acad. Sci. USA, 116, 17666-17672, https://doi.org/10.1073/pnas.1907871116, 2019.

Koppers, A. A. P. and Coggon, R. (Eds): Exploring Earth by Scientific Ocean Drilling: 2050 Science Framework, 124 pp., https://doi.org/10.6075/J0W66J9H, 2020.

Labonté, J. M., Lever, M. A., Edwards, K. J., and Orcutt, B. N.: Influence of igneous basement on deep sediment microbial diversity on the eastern Juan de Fuca ridge flank, Front. Microbiol., 8, 1434, https://doi.org/10.3389/fmicb.2017.01434, 2017.

Laske, G., Markee, A., Orcutt, J. A., Wolfe, C. J., Collins, J. A., Solomon, S. C., Detrick, R. S., Bercovici, D., and Hauri, E. H.: Asymmetric shallow mantle structure beneath the Hawaiian Swell-evidence from Rayleigh waves recorded by the PLUME network, Geophys. J. Int., 187, 1725-1742, https://doi.org/10.1111/j.1365-246X.2011.05238.x, 2011.

Leahy, G. M., Collins, J. A., Wolfe, C. J., Laske, G., and Solomon, S. C.: Underplating of the Hawaiian Swell: evidence from teleseismic receiver functions, Geophys. J. Int., 183, 313-329, https://doi.org/10.1111/j.1365-246X.2010.04720.x, 2010.

Lever, M. A., Rouxel, O. J., Alt, J., Shimizu, N., Ono, S., Coggon, R. M., Shanks III, W. C., Lapham, L., Elvert, M., Prieto-Mollar, X., Hinrichs, K.-U., Inagaki, F., and Teske, A.: Evidence for microbial carbon and sulfur cycling in deeply buried ridge flank basalt, Science, 339, 1305-1308, https://doi.org/10.1126/science.1229240, 2013.

Li, J., Paraskevi, M., Schubotz, F., Sylvan, J. B., Burgaud, G., Klein, F., Beaudoin, D., Wee, S. Y., Dick, H. J. B., Lott, S., Cox, R., Meyer, L. A. E., Quemener, M., Blackman, D. K., and Edgcomb, V. P.: Recycling and metabolic flexibility dictate life in the lower oceanic crust, Nature, 579, 250-255, https://doi.org/10.1038/s41586-020-2075-5, 2020.

Liu, C.-H., Huang, X., Xie, T.-N., Duan, N., Xue, Y.-R., Zhao, T.X., Lever, M. A., Hinrichs, K.-U., and Inagaki, F.: Exploration of cultivable fungal communities in deep coal-bearing sediments from $\sim 1.3$ to $2.5 \mathrm{~km}$ below the ocean floor, Environ. Microbiol., 19, 803-818, https://doi.org/10.1111/1462-2920.13653, 2017.

Majumdar, A. S., Ray, D., and Shukla, A. D.: Serpentinization of olivine-gabbro in Central Indian ridge: Insights into $\mathrm{H}_{2}$ production during alteration in lower oceanic crust and sustenance of life at slow-spreading ridges, Lithos, 374-375, 105730, https://doi.org/10.1016/j.lithos.2020.105730, 2020.

Mason, O. U., Nakagawa, T., Rosner, M., Van Nostrand, J. D., Zhou, J., Maruyama, A., Fisk, M. R., and Giovannoni, S. J.: First investigation of the microbiology of 
the deepest layer of ocean crust, PLoS One, 5, e15399, https://doi.org/10.1371/journal.pone.0015399, 2010.

Ménez, B., Pisapia, C., Andreani, M., Jamme, F., Vanbellingen, Q. P., Brunelle, A., Richard, L., Dumas, P., and Réfrégiers, M.: Abiotic synthesis of amino acids in the recesses of the oceanic lithosphere, Nature, 564, 59-63, https://doi.org/10.1038/s41586-0180684-z, 2018.

Meyer, J. L., Jaekel, U., Tully, B. J., Glazer, B. T., Wheat, C. G., Lin, H.-T., Hsieh, C.-C., Cowen, J. P., Hulme, S. M., Girguis, P. R., and Huber, J. A.: A distinct and active bacterial community in cold oxygenated fluids circulating beneath the western flank of the Mid-Atlantic ridge, Sci. Rep., 6, 22541, https://doi.org/10.1038/srep22541, 2016.

Morishita, T., Umino, S., Kimura, J.-I., Yamashita, M., Ono, S., Michibayashi, K., Tominaga, M., Klein, F., and Garcia, M. O.: Workshop report on hard-rock drilling into mid-Cretaceous Pacific oceanic crust on the Hawaiian North Arch, Sci. Dril., 26, 47-58, https://doi.org/10.5194/sd-26-47-2019, 2019.

Müller, R. D., Sdrolias, M., Gaina, C., and Roest, W. R.: Age, spreading rates, and spreading asymmetry of the world's ocean crust, Geochem. Geophy. Geosy., 9, Q04006, https://doi.org/10.1029/2007GC001743, 2008.

National Research Council: The AMSOC Project to Drill a Hole to the Mohorovicic Discontinuity, Prepared for the AMSOC committee by H. H. Hess, Division of Earth Sciences, Washington, D.C., USA, 5 pp., 1957.

Nigro, O. D., Jungbluth, S. P., Lin, H.-T., Hsieh, C.-C., Miranda, J. A., Schvarcz, C. R., Rappé, M. S., and Steward, G. F.: Viruses in the oceanic basement, mBio, 8, e02129-16, https://doi.org/10.1128/mBio.02129-16, 2017.

Ohira, A., Kodaira, S., Moore, G. F., Yamashita, M., Fujiwara, T., Kaiho, Y., Miura, S., and Fujie, G.: Active-source seismic survey on the northeastern Hawaiian Arch: insights into crustal structure and mantle reflectors, Earth Planets Space, 70, 121, https://doi.org/10.1186/s40623-018-0891-8, 2018.

Orsi, W. D., Edgcomb, V. P., Christman, G. D., and Biddle, J. F.: Gene expression in the deep biosphere, Nature, 499, 205-208, https://doi.org/10.1038/nature12230, 2013.

Phipps Morgan, J. and Chen, Y. J.: The genesis of oceanic crust: magma injection, hydrothermal circulation, and crustal flow, J. Geophys. Res.-Sol. Ea., 98, 6283-6297, https://doi.org/10.1029/92JB02650, 1993.

Quemener, M., Mara, P., Schubotz, F., Beaudoin, D., Li, W., Pachiadaki, M., Sehein, T. R., Sylvan, J. B., Li, J., Barbier, G., Edgcomb, V., and Burgaud, G.: Meta-omics highlights the diversity, activity and adaptations of fungi in deep oceanic crust, Environ. Microbiol., 22, 3950-3967, https://doi.org/10.1111/14622920.15181, 2020.

Sano, T., Miyoshi, M., Ingle, S., Banerjee, N. R., Ishimoto, M., and Fukuoka, T.: Boron and chlorine contents of upper oceanic crust: Basement samples from IODP Hole 1256D, Geochem. Geophy. Geosy., 9, Q12O15, https://doi.org/10.1029/2008GC002182, 2008.

Shah-Walter, S. R., Jaekel, U., Osterholz, H., Fisher, A. T., Huber, J. A., Pearson, A., Dittmar, T., and Girguis, P. R.: Microbial decomposition of marine dissolved organic matter in cool oceanic crust, Nat. Geosci., 11, 334-339, https://doi.org/10.1038/s41561-0180109-5, 2018.
Shor, G. G. and Pollard, D. D.: Mohole site selection studies north of Maui, J. Geophys. Res., 69, 1627-1637, https://doi.org/10.1029/JZ069i008p01627, 1964.

Spinelli, G. A., Giambalvo, E. R., and Fisher, A. F.: Sediment permeability, distribution, and influence on fluxes in oceanic basement, in: Hydrogeology of the Oceanic Lithosphere, edited by: Davis, E. E. and Elderfield, H., Cambridge Univ. Press, New York, USA, 151-188, 2004.

Staudigel, H., Hart, S. R., Schmincke, H.-U., and Smith, B. M.: Cretaceous ocean crust at DSDP sites 417 and 418: carbon uptake from weathering versus loss by magmatic outgassing, Geochim. Cosmochim. Ac., 53, 3091-3094, https://doi.org/10.1016/00167037(89)90189-0, 1989.

Stein, C. A. and Stein, S.: Constraints on hydrothermal heat flux through the oceanic lithosphere from global heat flow, J. Geophys. Res.-Sol. Ea., 99, 3081-3095, https://doi.org/10.1029/93JB02222, 1994.

Suzuki, Y., Yamashita, S., Kouduka, M., Ao, Y., Mukai, H., Mitsunobu, S., Kagi, H., D’Hondt, S., Inagaki, F., Morono, Y., Hoshino, T., Tomioka, N., and Ito, M.: Deep microbial proliferation at the basalt interface in aged oceanic crust, Communications Biology, 3, 136, https://doi.org/10.1038/s42003-020-08601,2020

Teagle, D. and Ildefonse, B.: Journey to the mantle of the Earth, Nature, 471, 437-439, https://doi.org/10.1038/471437a, 2011.

Teagle, D. A. H., Alt, J. C., Umino, S., Miyashita, S., Banerjee, N. R., Wilson, D. S., and the Expedition 309/312 Scientists: Proc. IODP, 309/312, Washington, DC (Integrated Ocean Drilling Program Management International, Inc.), https://doi.org/10.2204/iodp.pr.312.2006, 2006.

Ten Brink, U. S. and Brocher, T. M.: Multichannel seismic evidence for a subcrustal intrusive complex under Oahu and a model for Hawaiian volcanism, J. Geophys. Res., 92, 13687-13707, https://doi.org/10.1029/JB092iB13p13687, 1987.

Ten Brink, U. S. and Brocher, T. M.: Multichannel seismic evidence for variations in crustal thickness across the Molokai Fracture Zone in the Mid-Pacific, J. Geophys. Res., 93, 1119-1130, https://doi.org/10.1029/JB093iB02p01119, 1988.

Thorseth, I. H., Torsvik, T., Furnes, H., and Muehlenbachs, K.: Microbes play an important role in the alteration of oceanic crust, Chem. Geol., 126, 137-146, https://doi.org/10.1016/00092541(95)00114-8, 1995.

Tully, B. J., Wheat, C. G., Glazer, B. T., and Huber, J. A.: A dynamic microbial community with high functional redundancy inhabits the cold, oxic subseafloor aquifer, ISME J,, 12, 1-16, https://doi.org/10.1038/ismej.2017.187, 2018.

Umino, S., Miyashita, S., Hotta, F., and Adachi, Y.: Along-strike variation of the sheeted dike complex in the Oman Ophiolite: Insights into subaxial ridge segment structures and the magma plumbing system, Geochem. Geophy. Geosy., 4, 8618, https://doi.org/10.1029/2001GC000233, 2003.

Umino, S., Nealson, K., and Wood, B.: Drilling to Earth's mantle, Phys. Today, 66, 36-41, https://doi.org/10.1063/PT.3.2082, 2013.

Vance, D., Teagle, D. A. H., and Foster, G. L.: Variable Quaternary chemical weathering fluxes and imbalances in marine geochemical budgets, Nature, 458, 493-496, https://doi.org/10.1038/?nature07828, 2009. 
Watts, A. B. and ten Brink, U. S.: Crustal structure, flexure, and subsidence history of the Hawaiian Islands, J. Geophys. Res.-Sol. Ea., 94, 10473-10500, https://doi.org/10.1029/JB094iB08p10473, 1989.

Watts, A. B., ten Brink, U. S., Buhl, P., and Brocher, T. M.: A Multichannel seismic study of lithospheric flexure across the Hawaiian-Emperor Seamount Chain, Nature, 315, 105-111, https://doi.org/10.1038/315105a0, 1985.

Wolfe, C. J., Solomon, S. C., Laske, G., Collins, J. A., Detrick, R. S., Orcutt, J. A., Bercovici, D., and Hauri, E. H.: Mantle shear-wave velocity structure beneath the Hawaiian hot spot, Science, 326, 1388-1390, https://doi.org/10.1126/science.1180165, 2009.
Zucca, J. J. and Hill, D. P.: Crustal structure of the southeast flank of Kilauea volcano, Hawaii, from seismic refraction measurements, B. Seismol. Soc. Am., 70, 1149-1159, 1980.

Zucca, J. J., Hill, D. P., and Kovach, R. L.: Crustal structure of Mauna Loa volcano, Hawaii, from seismic refraction and gravity data, B. Seismol. Soc. Am., 72, 1535-1550, 1982. 